Review Article

\title{
FARM MANAGEMENT INFORMATION SYSTEMS: A CASE STUDY ON A GERMAN MULTIFUNCTIONAL FARM
}

\author{
Christoph Husemann ${ }^{1}$, Nebojša Novković
}

\begin{abstract}
Accurate and easy to use Farm Management Information Systems (FMIS) are of fundamental importance for a successful operational farm management. However, still today many farmers do not use FMISs for various reasons, like lack of knowledge and the complexity of many available FMISs. In particular for small to medium-sized farms and for multifunctional farms appropriate FMISs hardly exist.

This paper aims on the deduction of a concrete FMIS from a general FMIS. The concrete FMIS has to focus on the needs of medium-sized and multifunctional farms. This means that the farmer has to be empowered to allocate the scarce resources of the farm. Therefore, we picked a German farm from the state North Rhine Westphalia as a case-study to apply a system analysis. The case study farm helps to identify and to analyze relevant material and information flows, production processes, and their interconnections and synergies.
\end{abstract}

Key words: Management, Farm Information System.

JEL: $Q 12, Q 19$

\section{Introduction}

Accurate and easy to use Farm Management Information Systems (FMIS) are of fundamental importance for a successful operational farm management. Unfortunately, most farmers do not use FMISs when it comes to operate their business, despite the increasing professionalism in the agricultural sector and its increasing usage of IT technologies.

This research paper's subject are functioning FMISs for multifunctional farms that support farmers in managing their farms both effective and efficiently. Within the scope of this paper the term "Management" incorporates the following activities:

1 Christoph Husemann, Ph.D. candidate, University of Novi Sad, Faculty of Agriculture, Trg Dositeja Obradovica no. 8, 21000 Novi Sad, Serbia, Phone: +381 691512 415, E-mail: christoph.husemann@yahoo.de

2 Nebojša Novković, Ph.D., Full Professor, University of Novi Sad, Faculty of Agriculture, Trg Dositeja Obradovica no. 8, 21000 Novi Sad, Serbia, Phone: +381 62200 132, E-mail: nesann@polj.uns.ac.rs

EP 2014 (61) 2 (441-453) 
1. Planning;

2. Organization;

3. Monitoring;

4. Controlling.

This paper's objective is to deduction of a specific FMIS from a general FMIS to support the management of multifunctional and medium-sized farms. To test the developed FMIS we have introduced it to a multifunctional, medium-sized German farm, serving as a case study.

The intended FMIS has to accurately display all branches of the farm at hand, so that the newly developed FMIS represents a valuable tool for the farmer to successfully manage his farm. Successful farm management in this context means that the farmer is capable of allocating scarce resources in a way that maximizes his profit. To empower the farmer in achieving this aim the FMIS has to master the planning, the organization, the monitoring, and the controlling of all the farm's production and business processes. Besides, the FMIS has to pay special attention to the farm's internal interdependences of the different branches of production and services. Lastly, the FMIS has to be easy to understand and to use, and to be readily adaptable. Only then the system will be most likely used by the farmer. Only if all the mentioned conditions are met the IS might be capable of enhancing the farmer's decision making process and of finally increasing his/her income.

\section{Literature Review}

The skillful and conceived management is one of the most important success factors for today's farms (Mishra et al., 1999; Muhammad et al., 2004). Only when a farm is well managed, it can generate the funds to finance its sustainable development and thereby its survival in today's fast changing environment. However, a sophisticated management is a challenging and time-consuming task, and has to be organized as efficiently as possible (Forster, 2002; Doye et al., 2000).

Reasons that explain the importance of a sophisticated farm management are certainly diverse, however, three major factors have been identified in the ongoing academic discourse (Inderhees, 2006; Sørensen, Bochtis, 2010):

1. A complex environment;

2. Complex farm structures;

3. The introduction of modern technologies to the agricultural sector (Glauben et al., 2006).

The environment the farms are involved in has become more and more complex over the past decades. Until the late 1980s it was enough to supply a society with cheap and sufficient food products. Today however, much more is expected from the agricultural sector, in particular when it comes to environmental concerns (Rohwer, 2010). Overall the agricultural business has shifted from a simple production sector to a multifunctional service sector (Schöpe, 2005). The expectations incorporate compliance with regulations to be entitled for EU subsidies (Morgan et al., 2012; Sørensen, Bochtis, 2010), new and 
stricter guidelines for the use of agrochemicals (Villaverde et al., 2014), food safety (Magnuson et al., 2013) and animal welfare requirements and environmental concerns (Malcolm, 2004a; BMELV, 2004). Furthermore, agricultural production has become an international business because of the liberalization of agricultural markets (Weiss, Thiele, 2002; Mußhoff, Hirschauer 2004). Together with the decrease of shipment costs it became economically feasible to trade agricultural commodities on the world market. This development makes it possible that a farmer in one country is affected by a drought or a change of agricultural policy in another country by more volatile prices (Malcolm, 2004a; Kristensen, Halberg, 1997).

The second reason, why farm management became more and more difficult lays within the farms them-selves. In Germany the total number of farms has decreased since the 1970s whereas the cultivated area did not change substantially (C) Statistisches Bundesamt, 2012). Consequently, the remaining farms have become larger to benefit from economies of scale (Nause, 2003) but they also became more difficult to manage (Glauben et al., 2006). But not all farmers reacted in the way of augmenting their cultivated area. A significant number of farmers started to diversify the business, by introducing new branches of production, offering services or by starting direct-marketing of crops (Weiss, Thiele, 2002; Horstmann, Schulze, 2011). Either way, the management of farms became more complex.

Lastly, the introduction of modern technology contributed to the challenge of sophisticated farm management. In this context modern technology incorporates in particular the usage of PCs coupled with the application of the corresponding software of the financial statements of farms, planning tasks for land cultivation husbandry etc. Additionally, many farmer introduced GPS added tractors and "smart" machinery, GIS-supported landscape modeling and other state of the art technology, making special knowledge indispensable (Linseisen et al., 2000; Zeddies, 2001). All these technologies can be combined under the expression "Wired Farm" or "Precision Farming" (Sigrimis et al., 1999).

A major outcome of the three developments described is the generation of large data volumes. To handle and to benefit from theses enormous data volumes farmers have to be capable of performing the following tasks:

1. Collection of Data;

2. Processing of Data;

3. Providing Data;

4. Using Data.

To deal with these four tasks farmers have to introduce an integrated Information System (IS) - sometimes also called DSS (decision support systems). Integrated in this context means that the IS has to be the connecting part between the farm's ERP (enterprise resource planning system) and the FMIS (management information system), (Sørensen, Bochtis, 2010). Only when an IS fulfils, both the data handling and the integration requirements it can satisfy its overall goal, namely to make the available data usable (McCown, 2002; Bryant, 1999; Kuhlmann, Brodersen, 2001), to contribute to a better decision-making process, and finally 
to a better management of the farm (Fountas et al., 2005). At the end farm management is always about analyzing data and making choices in order to allocate the scarce resources of the farm in the best way (Malcolm, 2004b, Parker, 2003).

Today, most IS or DSS have a special focus. "Dairy Comp 305" for instance, is an IS especially for the herd management of milking cows (Cerosaletti et al., 2004, Enevoldsen et al., 1995), whereas MicroLEIS (Meyer et al., 2013), DSSAT (Sonam, Sawhney, 2014) are developed as very useful tools land cultivation. AFFOREST sDSS is especially developed for silvi-culturist (Orshoven et al., 2007) and StocKeeper for herd management of bulls (Grubb, 2010). Others, like FAMOUS e.g. focus particularly on huge and highly professional managed farms (Schmid, 2004). However, a well-designed and easy to use FMIS for medium-sized and multi-functional farms has not been developed yet.

\section{Methods and Data Sources}

In a first step, the authors reviewed historical and contemporary literature to analyze different general ISs. Then we examined the medium-sized, multifunctional German farm, which serves as a case study farm. The examination focused particularly on the question how this farm is organized and which kind of data is available. Therefore, we applied a system analysis to the case-study farm to identify and to analyze all the material and information flows, the production processes, and their interconnections and synergies. The data collection incorporated visual inspections (fields, animal facilities, machinery etc.), interviews with the farmer and his laborer and a thorough analysis of the farm's financial data, including balance sheets and profit and loss statements, the operating plan including spraying and fertilizing dates and crop rotation scenarios. We consequently aggregated the gathered information in a farm fact book comprising all relevant data concerning the external and internal conditions of the selected farm. Moreover, the collected data provided the basis for the development of an individual (specific/concrete) IS, which describes all relevant factors of the system like input and output prices, resources, production processes and activities, services and administration. We attached particular attention to the interconnections between the different production process to identify synergies between them these synergies might be positive and thereby increasing the overall farm profitability or they might be negative and thereby decreasing the overall farm profitability.

\section{Result of Research}

The research has started with a thorough System analysis of the case-study farm. This system analysis incorporated the preparation of "Farm fact book" as Figure 1 displays. The "Basic information" includes details about the "Legal status", "Mode of operation", and the "Aim of operation". The examined farm is like the vast majority of German farms an independent business, meaning that the farmer is personally liable for his farm. Despite the fact that the spouse of the farm is working externally the farm is considered a "Main income farm" since the farm supplies major funds to the total household income. The "Aim of operation" is of special interest respecting the scope of this paper. Unsurprisingly, the farmer named profit maximization as one goal. Moreover he plans to further develop 
"Direct marking" in connection with "Strawberry cultivation", since he considers this a growing market in the future. The most interesting point however, is the fact that the farmer himself obviously estimates that there is some optimization potential within his farm. This self-induced recognition plays a major role for the motivation later on during the introduction and application phase of the FMIS.

As for every farming business the "Natural conditions" are of vital importance. The local climate and the annual amount of rainfall provide good conditions for land cultivation. Additional most of the soil used for cultivation is of extraordinary quality.

Figure 1. Farm Fact Book

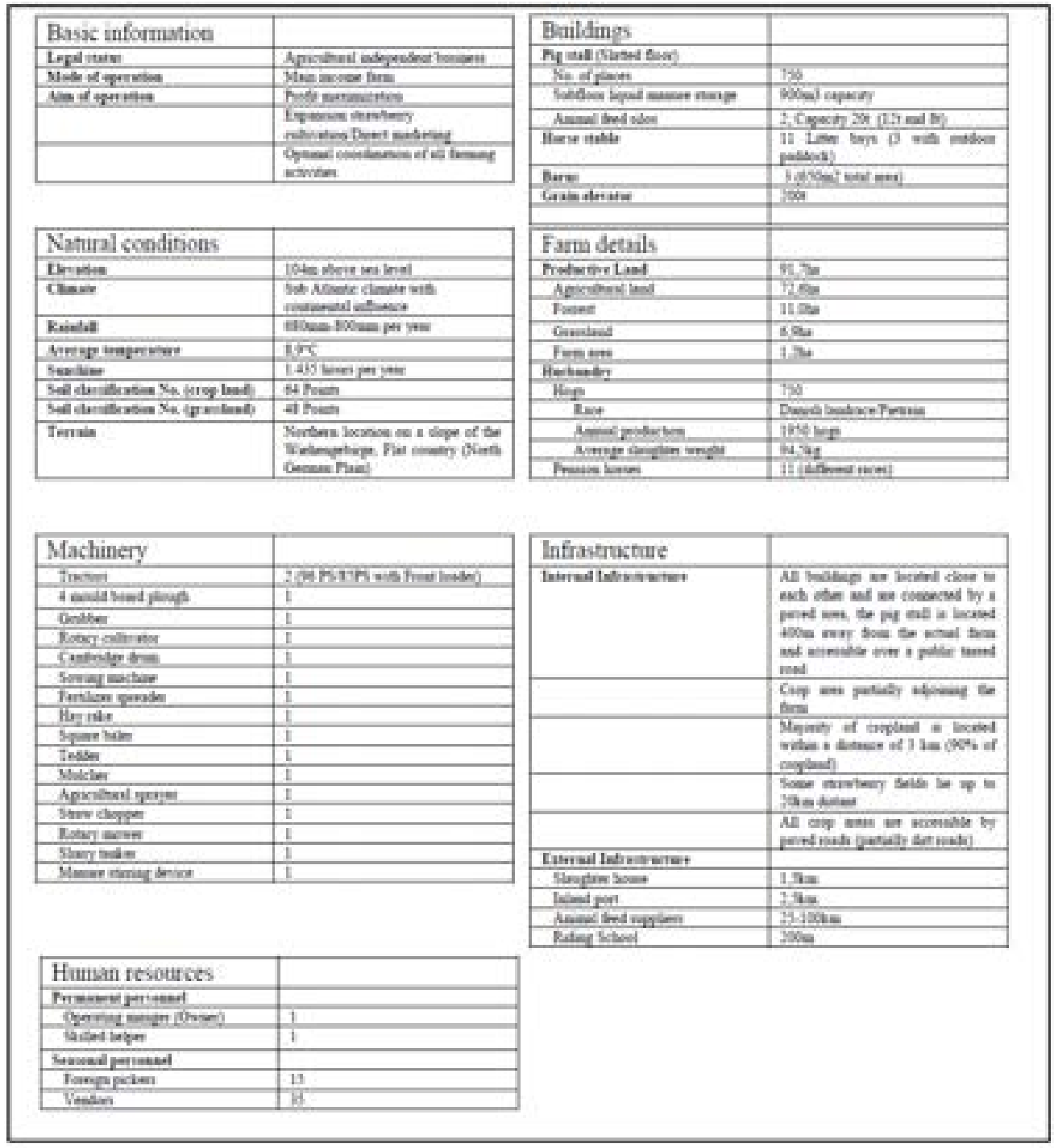

Source: Research results

EP 2014 (61) 2 (441-453) 
The so called loess soil is one of the riches soils existing. The soil quality of the farm's location is comparable with fertile areas such as the "Soester Börde" and the "Magdeburger Börde". For the examined farm one can state that these conditions are favorable.

The "Machinery" is generally in good condition, maintained regularly and on the latest state of technology. The $85 \mathrm{HP}$ tractor represents the only exception. It is more than 20 years old and although it was completely overhauled seven years ago it is not up to date. Thus the farmer intends to replace it within one year time.

The "Human resources" display three different types of employees. The farmer employs one additional full time helper. Due to the natural variation in work load between summer and winter a time account provides the flexibility needed. Beside the full time helper the farmer employs 15 foreign pickers and up to 35 vendors during the strawberry and raspberry season. Most pickers are of Polish origin whilst the vendors are mostly German pensioners, students or pupils. According to their occupational background all employees are either marginal employed or short term employed, to achieve a minimum tax charge.

"Buildings" incorporate all premises need for the production processes. The "Pig stall" was erected in 1978 and augmented in 1990 to a capacity of 750 hogs. The installation of a fully automated feeding system at the same time reduced the workload per hog dramatically. The stall serves additionally as a platform for solar panels. The 11 boxes for the pension horses are accommodated in two buildings, both build in 1975. Three boxes with outdoor paddock situated in one building, the residual ones in another. The average size of the boxes amounts to $16 \mathrm{~m} 2$ and all are equipped with automated drinking water supply. Barely- and wheat-straw serves as litter. All barns are more than 40 years old, however well maintained and appropriate equipped for storing machinery, tools, etc.

The "Farm details" display, how the 91,7ha "Productive land" are split up. As one can see the agricultural land represents by far the largest share. Forrest contributes the second largest part; however, its effect on the farm's total profitability is minor.

The "Internal" as well as the "External infrastructure" are advantageous. Concerning the internal infrastructure one can state, that all production facilities are located centrally at the farm. The majority of cultivated land is closely situated as well. Some strawberry fields represent exceptions, yet. The preference of many customers to swiftly access strawberry field for self-picking causes the wide dispersion of the fields. The "External infrastructure" provides all facilities to source raw material and to sell finished products cost efficient. The close-by riding school causes a constant need for horse boxes. The fact book provides valuable input for the setting up of the actual FMIS. It contains all the basic information needed for a germane development of the model and it helps the researcher to better understand the farm's productions processes and their interdependencies.

In a second step we analyzed three general FMIS models. Most FMIS models in literature have quite simple structure. The structure of the basic FMIS described in Figure 2 incorporates two different technologies, namely plant production (PP) and livestock production (LSP). When all activities and the input respectively output factors of these 
technologies are evaluated with prices, then an accurate calculation can be conducted. In terms of livestock production the "Herd Organization Structure" has to be considered additionally. From the calculations of both the plant production and the livestock production one receives the coefficients necessary for the linear programming program (LP-Program). This program also considers market limitations (e.g. max. quality sellable of a good) and production limitations (e.g. the max. available agricultural land).

Figure 2. Basic FMIS

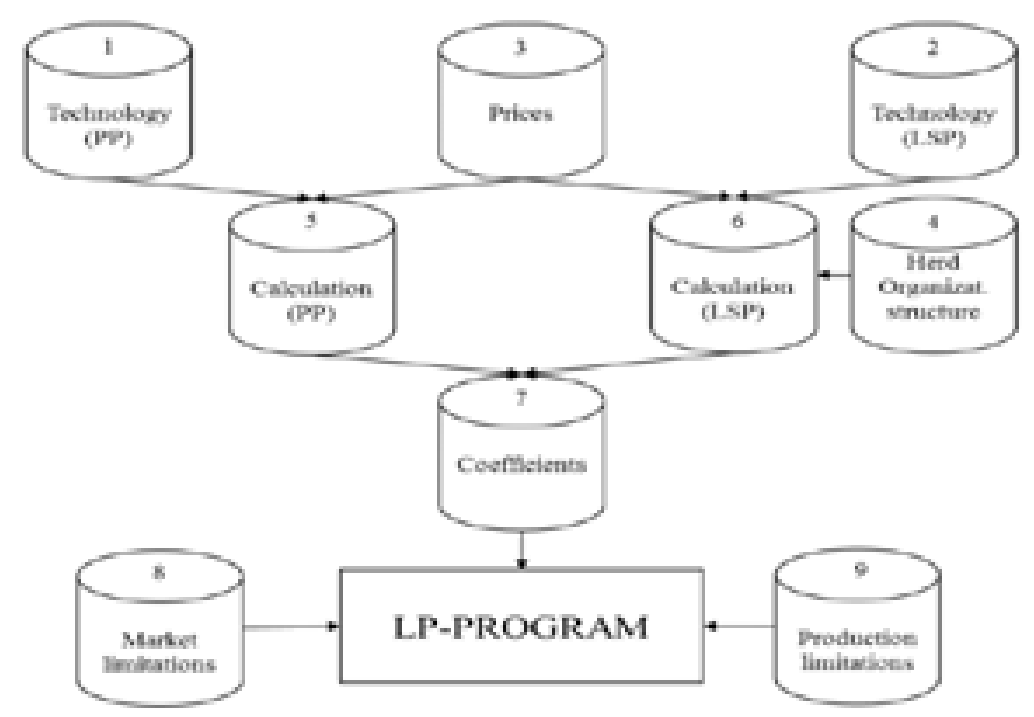

Source: Research results

The basic FMIS shown can only describe the general way of what FMISs should comprise. However, when adapted for real farms many more factors have to be considered. This statement holds unparticular true, when it comes to multifunctional farm with their complex farm structure and their internal connections between the different production process and services.

The analyzed case study farm is a good example of such a complex farm structure. As Figure 3 displays the case-study farm has three major braches, namely "Plant Production", "Services" and "Livestock Production". The branch "Plant Production" has four subunits. The first subunit, called "Arable Farming" displays the three main crops, which the farmer cultivates. These crops follow the common regional scheme of crop rotation: winter wheat, winter barely, winter canola. Grain maize is only occasionally cultivated as a surrogate crop in the case that the three main crops could not be cultivated. "Feed Crops" incorporates grassland for the hay production and grain maize, which is sold to food suppliers who meliorate and resell it as pig feed to the farmer. The pasture is exclusively used for the horses during the summer. The "Permanent Crops" are of particular importance for two reasons. Both, strawberries and raspberries contribute substantially to the total farm income. They are the only products sold directly to end consumers and they are therefore closely related to the service "Direct Marketing". 
"Services" are the second major branch and consists of "Lease of Land", "Lease of Equipment", "Pension Horses", "Forestry", and "Direct-Marketing". "Forestry" and "Lease of Equipment" are of minor importance, since they only occasionally contribute to the farm's income. In contrast, "Lease of Land" is more important. Since 2010 on average more than 10 ha per year were leased to potato farmers.

Figure 3. Farm structure of the case-study farm

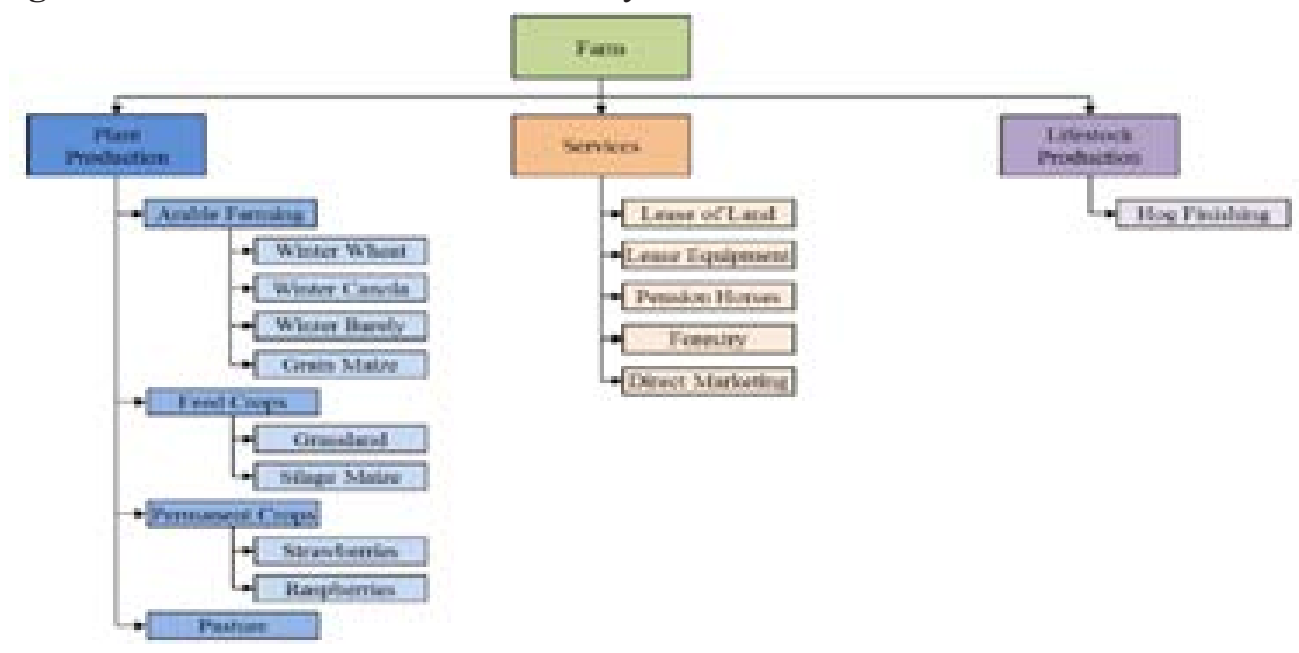

Source: Research results

Also "Pension Horses" are a moderate source of income. As mentioned earlier, the "DirectMarketing" plays a major role for the total farm income in combination with the permanent crops strawberries and raspberries. The branch "Livestock Production" solitarily deals with "Hog Finishing". The 700 place of the hog stable are the biggest source of income of the case study farm, which is totally independent of the season.

Figure 4. Internal connections of different branches of production

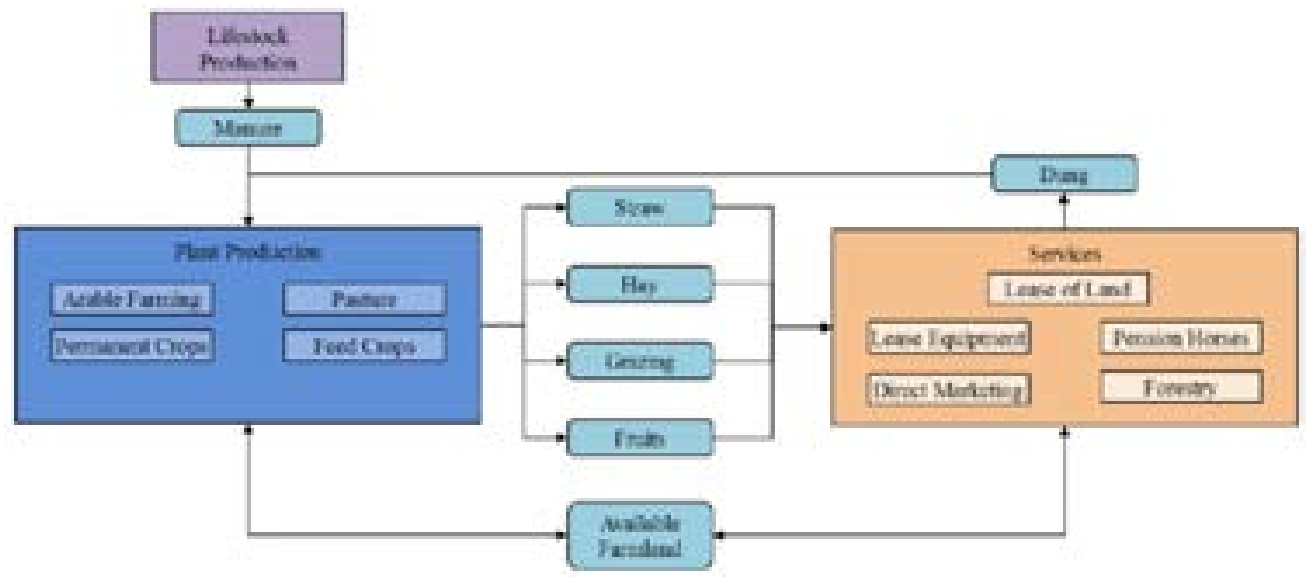

Source: Research results 
The interconnection of the different production process and services are explained in Figure 4 and Figure 5. Figure 4 shows the interconnection between the main branches "Plant Production", "Services" and "Livestock Production" whereas Figure 5 displays the interconnection on a subunit level.

As one can observes in both diagrams natural fertilizer in the form of manure and dung is applied in the plant production process. The source for the manure is the "Hog Finishing" and for the dung the source is the "Pension Horses" service. The other way round "Plant Production" is providing hay, straw and pasture to the "Pension horses". A special relationship exists between "Plant Production" and the service "Lease of Land". As the double-headed arrows indicate the connection works in both directions. As more arable land is used for the "Plant Production" as less can be used for the lease to other farmers and vice versa.

Figure 5. Internal connections of different production processes

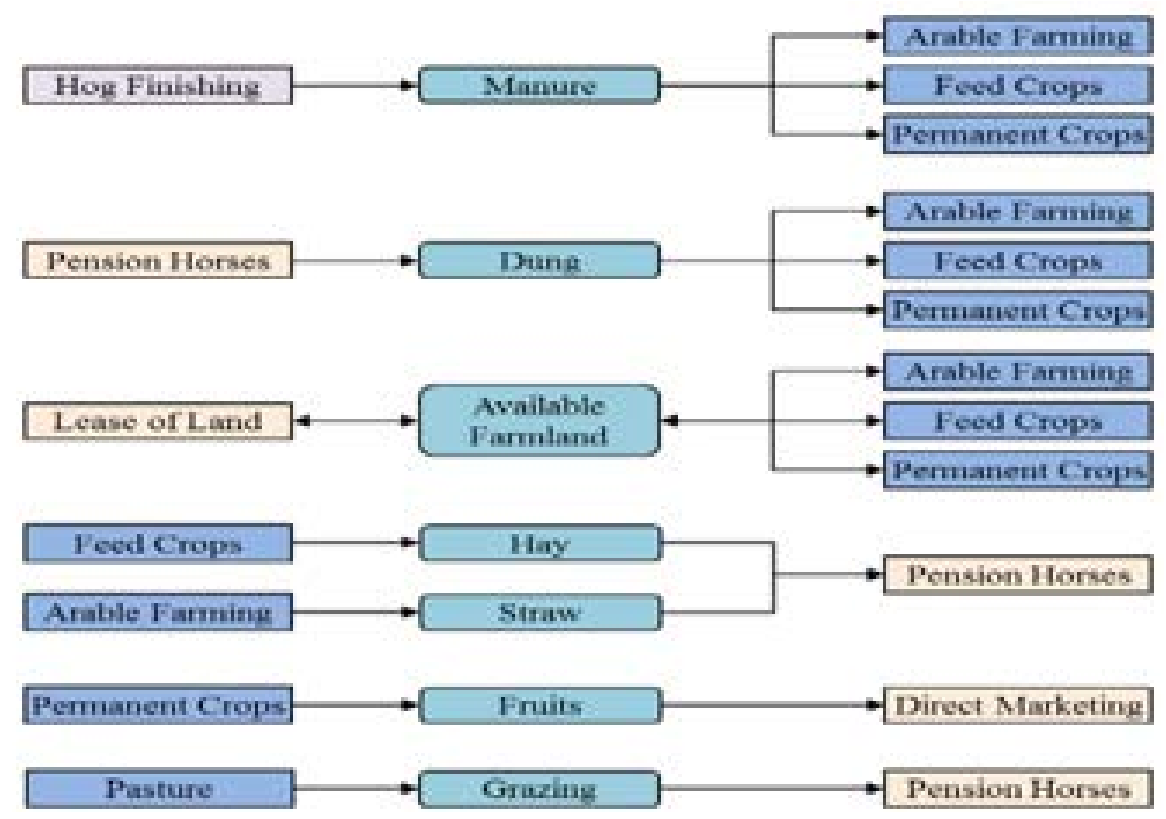

Source: Research results

\section{Conclusion}

Based on the general FMIS model and the selected data from the case-study farm we developed a FMIS that suits the needs of the case-study farm including an easy adaptation, user-friendliness, and accuracy in depicting the various production processes and services. Our research shows that basic FMISs provide an adequate general structure and the basic functionalities for concrete FMISs. However, when it comes to an application on real farms, a lot of adjustments have to be made to depict all production processes accurately. This statement holds in particular true for multifunctional farm with their complex farm EP 2014 (61) 2 (441-453) 
structure and their internal interconnections and synergy effects between internal production processes and services. How much effort is needed depends on the complexity of the farm at hand.

An elaborate FMIS provides a series of advantages for the farmer. He is not any longer solitarily dependent on his "gut feeling". He becomes capable of quickly realizing divergences between the planed and the actual business performance and he can therefore apply counter measures earlier. Furthermore, he can save time on collecting and organizing data that he has to provide to authorities.

Overall, a well-designed FMIS well increase the total profit of a farm and therefore help to survive in today's fast changing and highly competitive environment.

\section{References}

1. C Statistisches Bundesamt (2012): Statistisches Bundesamt Deutschland - GENESISOnline, Wiesbaden, available at: https://www-genesis.destatis.de/, accessed 17 January 2012.

2. BMELV (2004): Stellungnahme des wissenschaftlichen Beirats Agrarpolitik, nachhaltiger Landbewirtschaftung und Entwicklung ländlicher Räume beim Bundesministerium für Verbraucherschutz, Ernährung und Landwirtschaft zu den Beschlüssen des Rates der Europäischen Union zur Reform der Gemeinsamen Agrarpolitik vom 26. Juni 2003, Berichte über Landwirtschaft, Jg. 82, Heft 2.

3. Bryant, L. (1999): Computers on the Farm. Farmers' usage patterns and impact on farm management, A report for the Rural Industries Research, RIRDC Publication, no. 99/13.

4. Cerosaletti, P.E., Fox, D.G., Chase, L.E. (2004): Phosphorus Reduction Through Precision Feeding of Dairy Cattle, Journal of Dairy Science, Vol. 87, no. 7, pp. 2314-2323.

5. Doye, D., Jolly, R., Hornbaker, R., Cross, T., King, R.P., Lazarus, W.F., Yeboah, A. (2000): Case Studies - Case Studies of Farmers'Use of Information Systems, Review of agricultural economics RAE, Vol. 22, no. 2, pp. 566-585.

6. Enevoldsen, C., Sørensen, J.T., Thysen, I., Guard, C., Gröhn, Y.T. (1995): A Diagnostic and Prognostic Tool for Epidemiologic and Economic Analyses of Dairy Herd Health Management, Journal of Dairy Science, Vol. 78, no. 4, pp. 947-961.

7. Forster, R. (2002): Methodische Grundlagen und praktische Entwicklung eines Systems zur Planung dispositiver Arbeiten in landwirtschaftlichen Unternehmen, Techn. Univ, München, 2002.

8. Fountas, S., Blackmore, S., Ess, D., Hawkins, S., Blumhoff, G., Lowenberg-Deboer, J., Sorensen, C.G. (2005): Farmer experience with precision agriculture in Denmark and the US Eastern Corn Belt, Precision Agriculture, Vol. 6, no. 2, pp. 121-141.

9. Glauben, T., Tietje, H., Weiss, C. (2006): Agriculture on the move: Exploring regional differences in farm exit rates in Western Germany, Jahrbuch für Regionalwissenschaft, Vol. 26, no. 1, pp. 103-118. 
10. Grubb, J. (2010): A Low Cost Automated Livestock Tracking System, Appalachian State University, 2010.

11. Horstmann, F., Schulze, B. (2011): Landwirtschaftliche Direktvermarktung: Neue Potenziale durch Social Media? Einsatz eines UAV zur Erfassung von multispektralen Reflexionseigenschaften in Winterweizen, GIL Jahrestagung 2011, pp. 97-100

12. Inderhees, P.G. (2006): Strategische Unternehmensführung landwirtschaftlicher Haupterwerbsbetriebe: Eine Untersuchung am Beispiel Nordrhein-Westfalens: Strategic management of agriculture farming: Analysis at the example of North-Rine Westfalia, Niedersächsische Staats und Universitätsbibliothek, Göttingen.

13. Kristensen, E.S., Halberg, N. (1997): A systems approach for assessing sustainability in livestock farms, In Sørensen, J.T. (Ed.), Proceedings of the fourth international symposium of Livestock Farming systems, EAAP Satellite Symposium., Wageningen Pers, EAAP Publication, no. 89, pp. 16-29.

14. Kuhlmann, F., Brodersen, C. (2001): Information technology and farm management: developments and perspectives, Computers and Electronics in Agriculture, Vol. 30, no. 1, pp. 71-83.

15. Linseisen, H., Spangler, A., Hank, K. (2000): Daten, Datenströme und Software in einem Informationssystem zur teilflächenspezifischen Pflanzenproduktion, Zeitschrift für Agrarinformatik, Vol. 2, pp. 36-42.

16. Magnuson, B., Munro, I., Abbot, P., Baldwin, N., Lopez-Garcia, R., Ly, K., McGirr, L., Roberts, A., Socolovsky, S. (2013): Review of the regulation and safety assessment of food substances in various countries and jurisdictions, Food additives \& contaminants. Part A, Chemistry, analysis, control, exposure \& risk assessment, Vol. 30, no. 7, pp. $1147-1220$.

17. Malcolm, B. (2004a): Farm Management analysis: a core discipline, simple sums, sophisticated thinking, AFBM Journal, Vol. 1, no. 1, pp. 45-56.

18. Malcolm, B. (2004b): Where's the economics? The core discipline of farm management has gone missing!, The Australian Journal of Agricultural and Resource Economics, Vol. 48 No. 3, pp. 395-417.

19. McCown, R.L. (2002): Changing systems for supporting farmers' decisions: problems, paradigms, and prospects, Agricultural Systems, Vol. 74 No. 1, pp. 179-220.

20. Meyer, A.D., Estrella, R., Jacxsens, P., Deckers, J., van Rompaey, A., van Orshoven, J. (2013): A conceptual framework and its software implementation to generate spatial decision support systems for land use planning, Land Use Policy, Vol. 35, no. 0, pp. 271-282.

21. Mishra, A.K., El-Osta, H.S., Steele, C.J. (1999): Factors affecting the profitability of limited resource and other small farms, Agricultural finance review, Vol. 59, pp. 77-91.

22. Morgan, W., Cotter, J., Dowd, K. (2012): Extreme Measures of Agricultural Financial Risk, Journal of Agricultural Economics, Vol. 63, no. 1, pp. 65-82.

23. Muhammad, S., Tegegne, F., Ekanem, E. (2004): Factors contributing to success of small 
farm operations in Tennessee, Age (years), Vol. 6, pp. 15-4.

24. Mußhoff, O., Hirschhauer, N. (2004): Optimierung unter Unsicherheit mit Hilfe stochastischer Simulation und genetischer Algorithmen. dargestellt anhand der Optimierung des Produktionsprogramms eines Brandenburger Marktfruchtbetriebes, German Journal of Agricultural Economics, Vol. 53, no. 7, pp. 264-279

25. Nause, G. (2003): Zur Entwicklung der in den landwirtschaftlichen Betrieben Deutschlands beschäftigten Arbeitskräfte 1991 bis 2001, Statistisches Bundesamt, Wirtschaft und Statistik, pp. 301-313.

26. Orshoven, J., Gilliams, S., Muys, B., Stendahl, J., Skov-Petersen, H., Deursen, W. (2007): Support of Decisions on Afforestation in North-Western Europe with the AFFORESTsDSS, in Heil, G., Muys, B., Hansen, K. (Eds.), Environmental Effects of Afforestation in North-Western Europe, Plant and Vegetation, Vol. 1, Springer Netherlands, pp. 227-247.

27. Parker, W.J. (2003): Why measures of farm business success matter, Proceedings of the New Zealand Grassland Association, Vol. 65, pp. 199-2004.

28. Rohwer, A. (2010): Die Gemeinsame Agrarpolitik der EU - Fluch oder Segen?, ifo Schnelldienst, no. 63, pp. 27-36.

29. Schmid, E. (2004): Das Betriebsoptimierungssystem FAMOS, Diskussionspapier / Institut für Nachhaltige Wirtschaftsentwicklung, [N.F.],9, Univ. für Bodenkultur Wien Dep. für Wirtschafts- u. Sozialwiss. Inst. für Nachhaltige Wirtschaftsentwicklung, Wien.

30. Schöpe, M. (2005): Die veränderte Rolle der Landwirtschaft zu Beginn unmittelbades 21. Jahrhunderts, ifo Schnelldienst, no. 58, pp. 21-26.

31. Sigrimis, N., Hashimoto, Y., Munach, A., Baerdmaeker, J.D. (1999): Prospects in agricultural engineering in the information age-technological developments for the producer and the consumer, Agricultural Engineering International: CIGR Journal.

32. Sonam, O.P. and Sawhney, B.K. (2014): Development of Software for Research Farm Management System, Development, Vol. 3, no. 1.

33. Sørensen, C.G. and Bochtis, D.D. (2010): Conceptual model of fleet management in agriculture, Biosystems Engineering, Vol. 105, no. 1, pp. 41-50.

34. Villaverde, J.J., Sevilla-Morán, B., Sandín-España, P., López-Goti, C., Alonso-Prados, J.L. (2014): Biopesticides in the framework of the European Pesticide Regulation (EC) No. 1107/2009, Pest management science, vol. 70, no. 1, pp. 2-5.

35. Weiss, C., Thiele, H. (2002): Diversifikation und Wachstum landwirtschaftlicher Unternehmen, Agrarwirtschaft, Vol. 51, no. 3, pp. 156-163.

36. Zeddies, J. (2001): Modellierung von Betriebsentwicklung und Nachhaltigkeitszielen, Agrarwirtschaft, Vol. 50, no. 8, pp. 471-479. 


\title{
INFORMACIONI SISTEM ZA UPRAVLJANJE GAZDINSTVOM: STUDIJA SLUČAJA MULTIFUNKCIONALNOG GAZDINSTVA U NEMAČKOJ
}

\author{
Christoph Husemann ${ }^{3}$, Nebojša Novkovic ${ }^{4}$
}

\begin{abstract}
Sažetak
Lako i tačno korišćenje Informacionog Sistema za Upravljanje Gazdinstvom (ISUG) je od fundamentalnog značaja za uspešni operativni menadžment. Ipak, ni do danas mnogi poljoprivredni proizvođači uopšte ne koriste ISUG, zbog različitih razloga, kao što je nedostatak znanja, ili sofisticiranost mnogih dostupnih ISUG-a. Za mala i srednja multifunkcionalna gazdinstva odgovarajući ISUG gotovo da i ne postoji.

Cilj ovog rada je da od opšteg ISUG, dedukcijom, kreira konkretni (primenljivi) ISUG. Konkretni ISUG je fokusiran na potrebe multifukcionalnih gazdindinstava srednje veličine. To znači da farmeri treba tržišno da alociraju resurse svog gazdinstva. Kao primer (studija slučaja) izabrana je farma u Nemačkoj, na kojoj je izvršena sistemska analiza gazdinstva i primena ISUG. Studija slučaja na odbranoj farmi pomaže da se identifikuju $i$ analiziraju svi materijalni i informacioni tokovi proizvodnih procesa $i$ sinergija njihovih elkemenata.
\end{abstract}

Ključne reči: Upravljanje, Informacioni sistem gazdinstva.

3 Christoph Husemann, M.A., Univerzitet u Novom Sadu, Poljoprivredni fakultet, Trg Dositeja Obradovića 8, 21000 Novi Sad, Srbija, Telefon: +381 691512 415, E-mail: christoph.husemann@yahoo.de

4 Prof. dr Nebojša Novković, redovni professor, Univerzitet u Novom Sadu, Poljoprivredni Fakultet, Trg Dositeja Obradovica 8, 21000 Novi Sad, Srbija, Telefon: +381 62200132 , E-mail: nesann@polj.uns.ac.rs

EP 2014 (61) 2 (441-453) 